\title{
CAMBRIDGE
}

\section{Outstanding Scholarship in Philosophy}

from Cambridge University Press

\section{Constructivism in Ethics}

Carla Bagnoli

\$95.00: Hb: 978-1-107-01921-8: $272 \mathrm{pp}$.

\section{What Logics Mean}

From Proof Theory to

Model-Theoretic Semantics

James W. Garson

\$85.00: Hb: 978-1-107-03910-0: 260 pp.

\$32.99: Pb: 978-1-107-61196-2
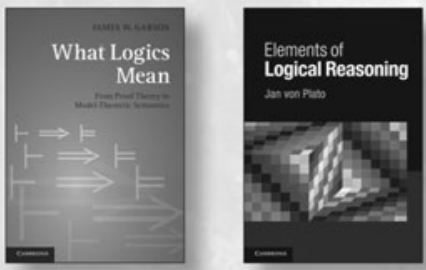

Elements of Logical Reasoning Jan von Plato

\$80.00: Hb: 978-1-107-03659-8: 271 pp.

\$29.99: Pb: 978-1-107-61077-4

Second Edition!

Modal Logic for Philosophers

James W. Garson

\$99.00: Hb: 978-1-107-02955-2: 508 pp.

\$42.99: Pb: 978-1-107-60952-5

Emotive Language in Argumentation

Fabrizio Macagno and Douglas Walton

\$90.00: Hb: 978-1-107-03598-0: 312 pp.

\$32.99: Pb: 978-1-107-67665-7

\section{Methods of Argumentation}

Douglas Walton

\$95.00: Hb: 978-1-107-03930-8: 318 pp.

\$32.99: Pb: 978-1-107-67733-3

\section{Ethics and Finance \\ An Introduction \\ John Hendry \\ Cambridge Applied Ethics \$85.00: Hb: 978-1-107-02422-9 \\ \$29.99: Pb: 978-1-107-61248-8: $318 \mathrm{pp}$.}

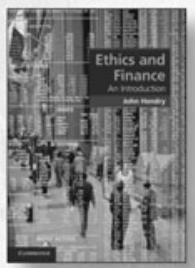

\section{Human Rights}

The Hard Questions

Cindy Holder and David Reidy \$99.00: Hb: 978-1-107-00306-4: 488 pp. \$34.99: Pb: 978-0-521-17626-2

\section{Ibn Gabirol's Theology of Desire}

Matter and Method in

Jewish Medieval Neoplatonism

Sarah Pessin

\$99.00: Hb: 978-1-107-03221-7: $280 \mathrm{pp}$.

Kierkegaard and the Problem of Self-Love

John Lippitt

\$99.00: Hb: 978-1-107-03561-4:222 pp.

Natural Categories and Human Kinds

Classification in the Natural and Social Sciences Muhammad Ali Khalidi

\$90.00: Hb: 978-1-107-01274-5: $264 \mathrm{pp}$.

www.cambridge.org/philosophy @CambUP_PHILNYUK 


\section{CAMBRIDGE}

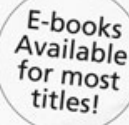

Outstanding Scholarship in Philosophy titles! from Cambridge University Press

\author{
Nietzsche's Philosophy of History \\ Anthony K. Jensen \\ \$90.00: Hb: 978-1-107-02732-9: $246 \mathrm{pp}$.
}

\section{Normativity and Phenomenology in Husserl and Heidegger}

Steven Crowell

\$85.00: Hb: 978-1-107-03544-7: 335 pp.

\$29.99: Pb: 978-1-107-68255-9

\section{Rousseau and German Idealism}

Freedom, Dependence and Necessity

David James

S99.00: Hb: 978-1-107-03785-4: $243 \mathrm{pp}$.

\section{Rousseau's Social Contract}

An Introduction

David Lay Williams

Cambridge Introductions to

Key Philosophical Texts

\$80.00: Hb: 978-0-521-19755-7: 324 pp.

S29.99: Pb: 978-0-521-12444-7

\section{Schopenhauer}

and the Aesthetic Standpoint

Philosophy as a Practice of the Sublime

Sophia Vasalou

S90.00: Hb: 978-1-107-02440-3: 244 pp.

The Cambridge Companion to Pragmatism

Alan Malachowski

Cambridge Companions to Philosophy

S99.00: Hb: 978-0-521-11087-7: $396 \mathrm{pp}$.

\$29.99: Pb: 978-0-521-12580-2

\section{The Pragmatic} Enlightenment

Recovering the

Liberalism of Hume, Smith, Montesquieu, and Voltaire

Dennis C. Rasmussen \$90.00: Hb: 978-1-107-04500-2: $357 \mathrm{pp}$.

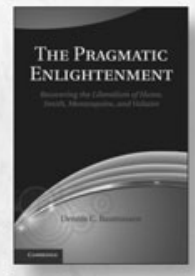

\section{The Nature of Life}

Classical and Contemporary Perspectives from Philosophy and Science

Mark A. Bedau and

Carol E. Cleland

\$151.00: Hb: 978-0-521-51775-1: 440 pp.

The Sublime in Modern Philosophy

Aesthetics, Ethics, and Nature

Emily Brady

\$90.00: Hb: 978-0-521-19414-3: 237 pp.

\section{Tyranny}

A New Interpretation

Waller R. Newell

\$95.00: Hb: 978-1-107-01032-1: 552 pp.

\$29.99: Pb: 978-1-107-61073-6
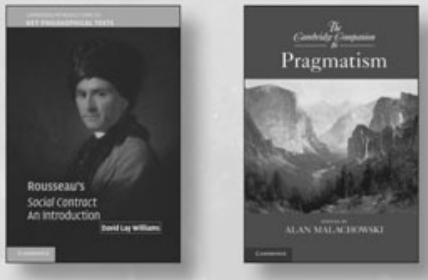

Price subject to change.

www.cambridge.org/philosophy (a)CambUP_PHILNYUK 


\section{CAMBRIDGE JDURNALS}

\section{Hegel Bulletin}

Published for the Hegel Society of Great Britain

\section{Editor}

Katerina Deligiorgi, University of Sussex, UK

Hegel Bulletin is a leading English language journal for anyone interested in Hegel's thought, its context, legacy and contemporary relevance. The Bulletin aims to promote high quality contributions in the field of Hegel studies which is broadly construed to include all aspects of Hegel's thought, and its relation and relevance to the history of philosophy; Hegelian contributions to all aspects of current philosophical enquiry; German and British Idealism, Marx and Marxism, Critical Theory, American Pragmatism; and studies in the reception history of Hegel and German Idealism.

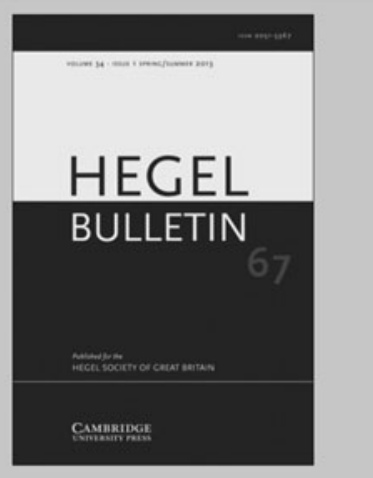

Hegel Bulletin

is available online at: http://journals.cambridge.org/hgl

\section{Customer Services}

Americas:

Phone + 1 (845) 3537500

$\mathrm{Fax}+1$ (845) 3534141

Email

subscriptions_newyork@cambridge.org

\section{Rest of world:}

Phone +44(0) 1223326070

$\mathrm{Fax}+44(0) 1223325150$

Email journals@cambridge.org

\section{Free email alerts}

Keep up-to-date with new material - sign up at

journals.cambridge.org/hgl-alerts 


\section{CAMBRIDGE JDURNALS}

\section{Religious Studies}

An International Journal for the Philosophy of Religion

\section{Editor}

Robin Le Poidevin, University of Leeds, UK

Religious Studies is an international journal devoted to the problems of the philosophy of religion as they arise out of classical and contemporary discussions and from varied religious traditions. Space is devoted to articles, of which more than 25 are published each year, and the journal also contains an extensive book review section, which includes review articles and book notes as well as normallength reviews.

\section{Price information}

\section{is available at: http://journals.cambridge.org/res}

\section{Free email alerts}

Keep up-to-date with new material - sign up at http://journals.cambridge.org/res-alerts

Religious Studies: An International Journal for the Philosophy of Religion

is available online at:

http://journals.cambridge.org/res

To subscribe contact Customer Services

in Cambridge:

Phone +44(0) 1223326070

$\mathrm{Fax}+44(0) 1223325150$

Email journals@cambridge.org

in New York:

Phone +1 (845) 3537500

$\mathrm{Fax}+1(845) 3534141$

Email

subscriptions_newyork@cambridge.org 


\section{Think}

Philosophy for everyone

Published for the Royal Institute of Philosophy

Editor

Stephen Law, Heythrop College, University of London, UK

Think has been created to forge a direct link between contemporary philosophy and the widest possible readership. The central aim of the journal is to provide to a very wide audience - encompassing undergraduates, ' $A$ ' level students, students in further education and the general public - highly accessible and engaging writing by philosophers pre-eminent in their fields. Think also aims to counter the popular impression that philosophy is pointless and wholly detached from everyday life Its contributors sometimes expose some of the bad philosophy which currently passes as accepted wisdom in certain circles (e.g. religious, scientific, anthropological, etc). Perhaps most importantly, Think gives contemporary philosophers the chance to help nurture and encourage philosophers of the next generation.

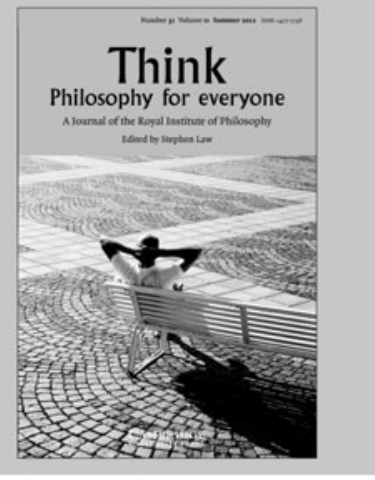

Think

is available online at: http://journals.cambridge.org/thi

To subscribe contact

Customer Services

\section{Americas:}

Phone +1 (845) 3537500

$\mathrm{Fax}+1(845) 3534141$

Email

subscriptions_newyork@cambridge.org

\section{Rest of world:}

Phone +44(0) 1223326070

$\mathrm{Fax}+44(0) 1223325150$

Email journals@cambridge.org

\section{Free email alerts}

Keep up-to-date with new material - sign up at

journals.cambridge.org/register 


\section{CAMBRIDGE JDURNALS}

\section{Utilitas}

Editor

Brad Hooker, University of Reading, UK

Utilitas is one of the leading international journals in ethics, offering high quality research in all aspects of the development of utilitarian thought and in all areas in which utilitarianism has made a contribution. As a pioneering, interdisciplinary journal, Utilitas will be of interest not only to moral philosophers but also to economists, political theorists, intellectual historians and legal theorists.

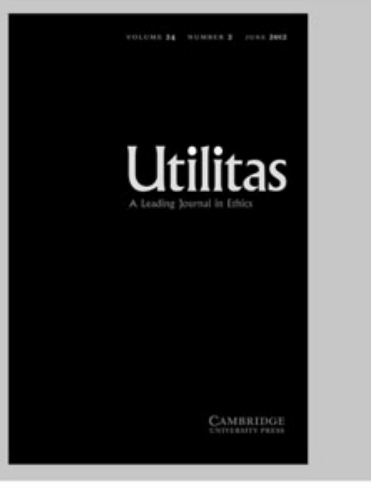

\section{Utilitas}

is available online at:

http://journals.cambridge.org/uti

To subscribe contact

Customer Services

Americas:

Phone +1 (845) 3537500

$\mathrm{Fax}+1(845) 3534141$

Email

subscriptions_newyork@cambridge.org

\section{Rest of world:}

Phone +44(0) 1223326070

$\mathrm{Fax}+44(0) 1223325150$

Email journals@cambridge.org

Free email alerts

Keep up-to-date with new material - sign up at

journals.cambridge.org/register
For free online content visit: http://journals.cambridge.org/uti 


\section{Editorial Policy of Philosophy}

The editorial policy of the journal pursues the aims of the Institute: to promote the study of philosophy in all its branches: logic, metaphysics, epistemology, ethics, aesthetics, social and political philosophy and the philosophies of religion, science, history, language, mind and education. The Institute is not committed to any school or method and its membership is not restricted to those with special qualifications in philosophy. Contributors are expected to avoid all needless technicality.

\section{Instructions for Contributors}

Prospective authors should email their contributions as .doc files (not pdfs) to assistant@royalinstitutephilosophy.org Contributions should on no account be longer than 10,000 words. Generally speaking far shorter is much to be preferred.

Authors should observe the conventions of the journal. The Editor will alter manuscripts wherever necessary to make them conform to journal style.

Quotation marks

Single quotation marks should be used except where there is a quotation within another.

E.g. 'He cried out "one should only use double quotation marks within single quotation marks", and stormed off.'

Unless the punctuation is an integral part of the quotation, it should be outside the quotation marks.

E.g. She looked up and asked 'Like this?'

He nodded and replied 'yes, that's exactly right'.

Titles of articles should be in single quotation marks. Scare quotes should be in single quotation marks.

Italics

The titles of books and journals should be in italics.

Foreign words and phrases should be in italics.

E.g. 'reductio ad absurdum' and 'a priori'.

Hyphens, en-rules, em-rules

En-rules should be used for parentheses, rather than em-rules.

E.g. 'en-rules are - according to Hart's rules - the most appropriate for London journals.'

NOT

'en-rules are-according to Hart's rules—the most appropriate for London journals.'

En-rules should be used to indicate ranges, rather than hyphens.

E.g. ' $136-234$ '

NOT

$135-234$

Footnotes

Notes and references will be printed as footnotes. Citations should also be given as footnotes and should appear as follows:

1. John Hyman, 'Pains and Places', Philosophy 78 (2003), 5-24

2. R. B. Louden, Morality and Moral Theory (New York and Oxford: Oxford University Press, 1992).

3. Op. cit. note 1, 101-112.

NOTE - do not include 'pp.' or 'p.' to indicate pages.

Structure

Sub-sections should be headed with Arabic rather than Roman numerals.

Abstracts should appear at the start of articles, and should be between 100 and 200 words in length.

At the end of articles, the author's biographical note will be inserted. This will include the author's name, email (unless otherwise stipulated by the author), and a couple of sentences detailing research interests and recent publications.

SEBASTIEN WINSTANLEY(swinstanley@bies.ac.uk) is Professor of Philosophy at the British Institute of Ephemeral Studies. His recent publications include The Disappearance of Nothingness (Arcana Press, 2011) and Death, My Friend (Moribunda, 2013).

Only corrections of typesetter's errors can be allowed in proofs. Authors are therefore asked to send any alterations or additions to Professor O'Hear as soon as possible after receiving his letter of acceptance.

Authors of articles, discussion papers and review articles will receive a pdf offprint free of charge. Print offprints may be purchased from the publisher if ordered at proof stage. Authors will also receive a copy of the issue in which their article appears.

Books for review should be sent to the Editor at the Institute and not to Cambridge University Press. Publishers are asked to note that non-philosophical works are not reviewed in Philosophy

Contributors of accepted articles will be asked to assign their copyright (on certain conditions) to the Royal Institute of Philosophy so that their interest may be safeguarded.

Authors are responsible for obtaining permission to reproduce any material in which they do not own copyright, to be used in both print and electronic media, and for ensuring that the appropriate acknowledgements are included in their manuscript.

Authors' corrected proofs should be sent via email to assistant@royalinstitutephilosophy.org.

\section{Internet Access}

This journal is included in the Cambridge Journals Online service which can be found at http://journals. cambridge.org. For further information on other Press titles access http://www.cambridge.org.

This journal issue has been printed on FSC-certified paper and cover board. FSC is an independent, nongovernmental, not-for-profit organization established to promote the responsible management of the world's forests. Please see www.fsc.org for information.

\section{CAMBRIDGE UNIVERSITY PRESS}

The Edinburgh Building, Cambridge CB2 8RU, United Kingdom

32 Avenue of the Americas, New York, NY 10013-2473, USA

477 Williamstown Road, Port Melbourne, VIC 3207, Australia

C/Orense, 4, planta 13, 28020 Madrid, Spain 


\section{PHILOSOPHY}

\section{volume 89 number 348 April 2014}

I97 Editorial: Hard men

Joint winner of the 2013 Philosophy prize essay competition

I99 There are no good objections to substance dualism JOSÉ GUSMÃO RODRIGUES

Joint winner of the 2013 Philosophy prize essay competition

223 The Grammar of Experience MARIAM THALOS

Articles

25I Later Wittgenstein's Anti-Philosophical Therapy DALE JACQUETTE

273 Notes Towards A Definition of Politics JAMES ALEXANDER

30I Irreducible Freedom in Nature JENNIFER CAMPBELL

325 What Does Ivan Ilyich Need To Be Rescued From? GERALD LANG

349 Reviews

373 Booknotes

377 Books Received

Cambridge Journals Online For further information about this journal please go to the journal website at: journals.cambridge.org/phi
CAMBRIDGE UNIVERSITY PRESS 